\title{
第37回 日本細菌学会関西支部総会
}

\author{
会 長 岸田綱太郎 (神戸常盤短大・微生物) \\ 期 日 昭和59年11月17日（土） \\ 会 場 神戸国際会議場中会議室（神戸市中央区港島中町 6丁目9-1）
}

\section{目次}

\section{特 別講 演}

輸入感染症の現状と展望……橋本 博（大阪市立住吉 市民病院）

\section{一般講演}

1. 細菌誘発インターフェロンの性状と産生細胞…… 山地正博*, 山田 修**, 荒木一美, 柳田潤一郎, 喜多正和，岸田綱太郎 (神戸常盤短大・微生物， *帝 国製薬，**扶桑薬品工業)

2. インターロイキン-2kよる $r$ 型インターフェロンの 産生一BCG 感染に上る增強一……岡村春樹, 長 田久美子, 和田正明*, 田村俊秀, 庄司 宏 (兵庫医 大・細菌, ${ }^{*}$ 四内)

3. デングウイルス特異的 IgE 抗体によるマウス肥満 細胞からの脱顆粒怙よびヒスタミンの遊離……ㄴ. Fernando Sanchez, 堀田 博, 本間守男 (神戸大. 医・微生物)

4. 非多発地に怙ける ATLV の家族内感染について… …森松伸一, 草壁秀成, 佐野浩一, 加藤公生, 飯 田恒二, 中井益代 (大阪医大・微生物)

5. 成人 T 細胞白血病ウイルス (ATLV) の超微細構造 ……平山公三, 杉田邦洋, 井村俊郎, 後藤俊幸, 中井益代（大阪医大・微生物）

6. 活性化マクロファージのヘルペスウイルス增殖抑制 ……奥 亨, ○長由紀枝, 稲川輔固, 田中淳夫, 桑山和加子, 今西二郎 (京都府立医大・微生物)

7. Mycobacterium bovis BCG のリボゾーム RNA 遺 伝子のクローニング……鈴木定彦, 永田昭久, 山 之内孝尚, 山田 毅 (阪大 - 微研), 吉永光一 (静岡 大・理)

8. 結核患者に拈ける結核菌および大腸菌の薬剤耐性獲
得の分子生物学的機構……只田 毅, 永田昭久, 小野泰子, 鈴木定彦，山之内孝尚（阪大・微研）

9. 微分干涉顕微鏡の微生物学領域への応用…… ○大山 昭夫, 伊藤富由, 山本典巳, 原 統子 (関西医大 微生物)

10. Campylobacter 属の培養細胞に対する感受性一特に マウス腹腔渗出細胞との相関についてー……伊藤 富由, 山本典巳, 谷村英紀, 吉城豊子, 大山昭夫 (関西医大・微生物)

11. Campylobacter jejuni の病原性に関する研究一第 6 報一……喜多英二, 勝井則明, 樫葉周三 (奈良医 大・細菌)，柳ヶ瀬康夫 (兵庫医大・細菌)

12. Campylobacter jejuni 拈よび Campylobacter coli に及ぼす胆汁の影響……石井営次，来住輝彦（大 阪市環科研・細菌), 田村俊秀 (兵庫医大 - 微生物), 增井正幹（大阪市大・医・細菌）

13. 嫌気連続培養に拈ける Escherichia coli の Shigella flexneri, Vibrio parahaemolyticus 於よび Staphylococcus aureus に対する強い增殖抑制……牛嶋

㟪, 高橋めぐみ，尾崎良克（滋賀医大・微生物）

14. 半流動寒天培地飞批けるYersinia 属菌の検討拈よ び增菌後の分離に及ぼす酢酸タリウムの選択性 (1) ……浜野理一郎, 佐々木美幸, 島田裕見子（箕面 市立病院)

15. Le:uconostoc mesenteroides B 1375 株が産生するデキ ストランの構造と特異性……鳥居光雄, 田中節子, 渡部一仁, 越川富比古, 山添をり (摄南大・薬・衛 生微生物)

16. Serratia 感染症 (Opłortunistic infection) に関する 一私見……多田宜文, 山口淳二 (近畿大. 医・細 菌)

17. Bacillus megaterium の芽胞形成期に括ける芽胞殸 たんぱく質の挙動……奥 裕一, 寺岡美恵, 大塚 幹子, E. I. フセイン, 中谷喜洋, 今川正良, 西原 
力, 近藤雅臣 (阪大・薬・衛生化学)

18. 性ホルモンの淋菌感染に及ぼす影響……西 一 幸, 江本正志, 喜多英二, 樫葉周三（奈良医大・細 菌)

19. Bacillus thuringiensis の産生する溶血毒……本田 武司, 芝 敦子, 三輪谷俊夫 (阪大・微研)

20. 豚由来毒素原性大腸菌 WT-1 が産生する LT の B subunit $の$ 一次構造……过 孝雄, 本田武司, 若 林貞夫*, 松原 央*, 三輪谷俊夫 (阪大 ・微研, *阪 大・理)

21. 乳のみマウス腸管液体賍溜をきたす $V$. cholerae non-O1 の産生する毒素……有田美知子, 本田武 司, 三輪谷俊夫 (阪大・微研)

22. コレラ毒素 および大腸菌易熱性毒素 (LTp 扣よび LTh）に対するウサギ抗血清中の共通抗体の定量的 解析……余 明順, 王 悦治, 辻 孝雄, 本田武 司, 三輪谷俊夫（阪大・微研）

23. Clostridium difficile の産生する enterotoxin に対 する抗体価の ELISA 法による測定……加藤隆 弘, 本田武司, 三輪谷俊夫 (阪大·微研)

24. 毒素原性大腸菌の 産生する ST の ELISA 法によ る定量……竹田多恵, ヌアルジラ・パタラランロ ソ, 本田武司, 三輪谷俊夫, 竹田美文*, W.ヘメル ホフ**, J.-P. バッラー** (阪大・微研, *東大・医 科研, **ベルギー自由大)

25. カルボシアニン色素による細菌・酵母のメタクロマ シ 一染色……大橋邦啓，梅田 優*，藤田益子， 丹羽 允 (大阪市大・医・細菌, *泌尿器)

26. カルボシアニン色素による真菌のメタクロマジー染 色……藤田益子, 大橋邦啓, 梅田 優*, 丹羽 允 (大阪市大・医・細菌, * 泌尿器)

\section{要旨}

\section{特別 講 演}

\section{輸入感染症の現状と展望}

橋本 博（大阪市立住吉市民病院）

わが国の近年に抢ける国際交流は航空機の発達によつ て全世界に拡がり，特に開発途上国との交流がますます 頻繁となつている。このような海外交流の激增は人や食 品を介して各種の感染症や検疫伝染病の国内持込みがみ られ，防疫対策上，医療上から重要課題である。輸入感
染症としてもつとも多いのは細菌性赤痢でA群菌，C群 菌など各種菌型が発見されている。

次いで多いのは腸チフス, パラチフスAでありアアメ 一バ赤㢉，マラリア，サルモネラ，腸炎ビブリオ感染が 扣もなものである。推定罹患国は北東アジア, 東南アシ ア，西南アジア諸国での感染が多くみられている。

これら輸入感染症の予防対策として国際空港の検疫体 制の強化, 第 1 線医療機関に対する啓蒙教育の充実, 患 者受入れ体制の整備, 海外渡航者への衛生教育の徹底が 要望される。

\section{一 般 講 演}

\section{1. 細菌誘発インターフェロンの性状と産生細胞}

○山地正博1), 山田 修2), 荒木一美, 柳田潤一郎, 喜多正和，岸田綱太郎（神戸常盤短大・微生物， ${ }^{1)}$ 帝 国製薬，2)扶桑薬品工業)

人末梢血を用いて各種細菌の IFN 誘発能を検討した 結果，多くの細菌に IFN 誘発能があつた。特に誘発能 の強かつた E. coli 抢よび $K$. pneumoniae を用いて, 誘発された IFN の性状を検討した結果，タイプは $\alpha$ 型 および $\gamma$ 型で， $\beta$ 型および酸不安定な $\alpha$ 型は検出されな かつた。また，誘発時間は， $\alpha$ 型は培養早期に， $\gamma$ 型は 後期であることがわからた。 $E$. coli を用いて IFN 産 生細胞を検討した結果， $\alpha$ 型産生細胞は B 細胞 および $\mathrm{NK}$ 細胞, $\gamma$ 型産生細胞は NK 細胞およびT細胞であ つた。ただし，NK 細胞は，細菌の直接作用で $\gamma$ 型 IFN を産生しているのに対して，T細胞は，単独では産生で きず，M $\phi$ の共存下において IFN 産生が可能であるこ とがわかつた。

\section{2. インターロイキン-2による $\gamma$ 型インターフェロン} の産生一BCG 感染による增強一

○岡村春樹, 長田久美子, 和田正明*, 田村俊秀, 庄 司 宏 (兵庫医大 $\cdot$ 細菌, $*$ 四内)

$\gamma$ 型インターフェロン (IFN- $\gamma$ ) は免疫応答における 役割が明らかになりつつあるが，その産生のしくみにつ， いての結論は得られていない。今回われわれはおもに腹 腔浸出細胞 (PEC) を用いて in vitro で IL-2 と LPS による IFN-r の産生を試みた。その結果 BCG 感染マ ウスの PEC はコントロールに比べてIL-2 によるIFN-r の産生能が数十倍高まつていること, LPS によつても IFN- $\gamma$ の産生が抗こること, IL-2 と LPS の間には相 乗作用があること，增強は PEC で顕著に見られ，リン 
パ節，脾，骨髄などの細胞には見られないこと，Tーリン パ球の存在が必要なことなどがわかつた。

このようなことは BCG 感染マウスが in vivo でLPS により多量の IFN- $\gamma$ を産生する現象と関連があるもの と思われる。

\section{3. テングウイルス特異的 IgE 抗体によるマウス肥} 满細胞からの脱顆粒およびヒスタミンの遊離

OL. Fernando Sanchez, 堀田 博, 本間守男（神戸 大・医・微生物)

デングウイルス (DV) 接種マウスの血清中に, DV 特 異的 IgE と思われる下記の性質を持つ抗体を検出した。

(1) マウス腹腔より得た肥満細胞に親和性を有する。(2) この感作肥満細胞に DV 抗原をチャレンジすると好塩 基性顆粒の脱顆粒およびヒスタミンの遊離をひきおこ す。(3) $56 \mathrm{C}, 60$ 分間の加熱処理によつて失活する。上記 の DV 特異的 $\operatorname{IgE}$ 抗体は初回免疫後 8 日後には検出さ れ，追加兔疫によつて継時的に増加した。

本実験系は, DV 感染における $\operatorname{IgE}$ 抗体の役割りを 解析するうえで有用であると思われる。

\section{4. 非多発地における ATLV の家族内感染について} ○森松伸一, 草壁秀成, 佐野浩一, 加藤公生, 飯田恒 二, 中井益代（大阪医大・微生物）

ATL 非多発地域である大阪近辺に打いて ATL 患者 を中心とした家族内 ATLA 抗体の検出を行つた。その 結果 ATL では出生地を問わず全例 ATLA 抗体陽性 であつた。配偶者は 4 名中 1 名が陽性で, 子供は11名中 4 名が陽性であつた。特に两親がともに陽性の場合，そ の子供は 4 名中 2 名が陽性であり，母親のみが陽性の場 合は 2 名とも陽性を示したが，父親のみが陽性の場合に はその子供は 5 名全員陰性であつた。

以上のことから家族内感染では母子感染の存在が感染 経路として強く示唆された。しかし，両親に扣ける夫婦 間感染については不明であつた。

\section{5. 成人 $\mathrm{T}$ 細胞白血病ウイルス (ATLV) の超微細構} 造

○平山公三, 杉田邦洋, 井村俊郎, 後藤俊幸, 中井益 代 (大阪医大・微生物)

ATL ウイルスを超薄切片法，ネザティブ染色法によ り電顕にて観察を行い以下の結果を得た。ウイルスは径 $94 \pm 22 \mu \mathrm{m}$ の類円形あるいは類棈円形で表面には突起様 構造が認められた。しかしこの突起様構造の存在につい
てはなおの詳細な検討が必要と思われる。また粒子の核 様体は超薄切片法で 6 角形, 8 角形, 10角形の多角を示 した。これらの多角形は正二十面体模型の回転角度変化 による投影像とよく一致するため正二十面体構造を呈し ているものと推察された。ネザティブ染色法では核様体 は交錯する線維状構造が膜様構造物の中に存在する像と して認められた。現在までの観察では未熟粒子の存在が 認められなかつた。以上の成績より ATLV は既知C粒 子と異なつた粒子であると推察した。

\section{6. 活性化マクロファージのヘルペスウイルス增殖抑} 制

奥 亨, ○長由紀枝, 稲川輔图, 田中淳夫, 桑山和 加子, 今西二郎 (京都府立医大・微生物)

活性化されたマクロファージとウイルス感染細胞とを 混合培養するとウイルス增殖抑制が見られる。この系を 用いて種々の薬剤の抗ウイルス性をスクリーニングした 結果, オリゴペプチド (FR 48217・FR 41565) 扩よび PSK を投与したマウスからの腹腔マクロファージに HSV 增殖抑制作用が認められた。すなわち Vero-HSV-1 の系に执いて FR 41565 は対照の $10^{-4} に$, FR 48217 は完全にウイルス増殖が抑えられた。PSK すウイルス 量を $10^{-2}$ に抑光た。またオリゴペプチドにはマウスの HSV 感染に対する防御勃果子認められ，FR 48217:6 $\mathrm{mg} / \mathrm{kg}$ 週一回投与群 $\cdot 0.2 \mathrm{mg} / \mathrm{kg} 4$ 日連投 3 日休薬群, FR $41565: 0.2 \mathrm{mg} / \mathrm{kg}$ 投与群には対照に比べ有意差が 認められた。

7. Mycobacterium bovis BCG のリボソーム RNA 逗伝子のクローニング

○鈴木定彦, 永田昭久, 山之内孝尚, 山田 毅(阪大・ 微研), 吉永光一(静岡大・理)

進化論的立場から考えて, 抗酸菌は非常に興味深い素 材である。現在までさまざまな研究がなされてきたが, その性質については，原核生物と真核生物の中間あると いら考えと、そうではなく単に厚い lipid rich な殸でお 特われているだけで中身は原核生物と変わらないといら 相対する 2 つの考光があり，いまだに決定的な結論は出 されていない。

われわれはこの問題に 対する 解答を出すために $M y$ cobacterium bovis BCG のリボゾーム RNA 遺伝子の解 析を行つて次のような知見を得た。1)リボゾーム RNA 遺伝子の数は一つである可能性が強かつた。2) リボゾー ム RNA 遺伝子を含む $7.4 \mathrm{kbp}$ の Pst I 断片をクロー 
ニングし，pBCG 1 と名づけ実験を進めた。3) R-loop 法 とサザンハイブリダイゼーション法を使つて遺伝子地図 を作製したところ，そのスペーサー領域は $0.37 \mathrm{kbp}$ ， $23 \mathrm{~S}$ 遺伝子は $2.9 \mathrm{kbp}$ であり, $16 \mathrm{~S}$ 遺伝子は $0.81 \mathrm{kbp}$ のみクローニングできていた。

\section{8. 結核患者における結核菌および大朋菌の菜郕耐性}

\section{獾得の分子生物学的機構}

○山田 毅, 永田昭久, 小野泰子, 鈴木定彦, 山之内 孝尚（阪大・微研）

国立療養所刀根山病院の入院患者の喀痰括よび䔬便か ら，薬剤耐性の結核菌抽よび大腸菌を分離精製した。得 られた菌株を增菌、集菌し、菌体を破碎後リボソーム画 分, 上清画分, および精製 RNA ポリメラーゼ (RPase) を得た。In vitro のコリシン DNA を template とす る RNA 合成系, poly(U) を template とする polyphenylalanine 合成系を作り, Rifampicin (RIF), kanamycin (KM), Viomycin (VM) 感受性をテストし た。大腸菌の RIF 耐性は plasmid により，伝達されず RPase が変化しているために耐性となつている。また， 培養での耐性度は同じでも，RPase の耐性度が異なる mutant がある。RPase の変化以外の機構が関与してい ることを示唆している。結核菌 5 株については, RIF 耐 性は RPase の変化, $\mathrm{KM}, \mathrm{VM}$ 耐性は, リボソームの 変化と透過性の変化が耐性の原因であることを示唆し た。

\section{9. 微分干涉顐微鏡の微生物学領域への応用}

○大山昭夫, 伊藤富由, 山本典巳, 原 統子 (関西医 大・微生物)

微分干渉顕微鏡 (DIC) の微生物学への応用を検討す る目的で位相差顕微鏡 (PCM) と比較しながら生の標本 を観察した。細胞レベルでの細菌に対する病原菌の感受 性については P. aeruginosa, C. jejuni および C. fetus と培養細胞との interaction を形態学的に観察した。特 に菌体と細胞との位置付け，および細胞の変性の状態も 像の高低差により観察することができた。一方, ウイル 又感染細胞に打いては CPE，あるいは封入体形成とい つた形態学的変化, 特に感染初期の微細な細胞変化を知 ることが困難な場合が多いが，Herpes simplex virus type 1, あるいは Mumps virus に执いて DICにより 感染初期の微細な細胞変化を生のまま経時的に観察する ことができた。すなわち，DICを用いた場合は，PCM， あるいは Giemsa 染色の平面的な像と異なり，表面の
構造のみならず立体的な像としてその位置的関係を正確 に把握することができた。

\section{Campylobacter 属の培誉細胞に対する感受性}

\section{一特にマウス腹腔缷出細胞との相関について一}

○伊藤富由, 山本典巳, 谷村英紀, 吉城豊子, 大山昭 夫 (関西医大・微生物)

Campylobacter 属の細胞感受性を求める目的でマウス 腹腔淩出細胞 (PEC), 並びに株化細胞に対する親和性を 形態学的な立場より検討した。各菌株の生菌をマウス ip に接種, 経時的に in vivo に拈ける腹腔内の生菌数を計 測すると C. fetus では接種後, 経時的に減少したが, C. fetus では PEC 内, 外ともに接種 2 時間後迄は生菌 数の変動はほとんど認められなかつた。一方, in vitro に抢いて培養 PEC に各菌株の生菌あるいは死菌を接触 させ, 篮光抗体染色法により観察すると両菌株とも経時 的に細胞内の菌体数は増加した。また, HeLa, Vero 細 胞に対しては C. fetus は接触 5 時間後に挍いても死菌 の場合と同様, 細胞内に菌体はほとんど認められなかつ たが，C. jejuni では経時的に細胞内の菌体は増加した。

\section{Campylobacter jejuni の病原性に関する研究一} 第 6 報一

○喜多英二, 勝井則明, 樫葉周三 (奈良医大・細菌), 柳ヶ瀬康夫 (兵庫医大・細菌)

C. jejuni Gifu 8734 株 $10^{5}$ をマウスに経口接種すると， 接種 5 日目以降から肝内より $10^{2} \sim 10^{3}$ の C. jejuni が回 収されるようになる。接種後 6 力月間の観察で, 長期に 渡つて排菌の接続したマウスの $80 \%$ が 6 力月目以降に死 亡し, 死亡したマウスの肝は肉眼的に萎縮状態を示し, さらに純培養状に C. jejuni が回収されるものがあつ た。接種後 1 力月毎にマウス血清中のGOT.GPT.ALP. LDH を測定すると, GOT.GPT.LDH は正常マウスの 值より上昇し, 特に $\mathrm{LDH}$ は, 20 倍以上の高值を示し た。抗 GIFU 血清を passive transfer することによ り, 腸管内での菌の定着阻止は認められたが, 肝内への 菌の移行は阻止できず，C. jejuni の細胞侵入は抗体の みでは防禦できなかつた。

\section{Compylobacter jejuni および Campylobacter} coli に及ぼす胆汁の影棌

○石井営次, 来住輝彦 (大阪市環科研 - 細菌), 田村俊 秀 (兵庫医大 - 細菌), 増井正幹 (大阪市大 $\cdot$ 医・細菌) 前報で各種胆汁酸類のらちコール酸に対し C. jejuni 
は C. coli よりも抵抗性の強い傾向があることを報告し た。今回 $C$. jejuni (人 2 , 牛 1 , 鼠 1 , 標準 1 株) $C$. coli（人 2 , 豚 2 , 標準 1 株）に対する牛および豚の胆 汁 (各 4 種類)による影響を調べた。胆汁中で初発菌濃 度 $10^{3} \sim 10^{5} \mathrm{CFU} / \mathrm{ml}$ で, 微好気下 $\left(\mathrm{N}_{2} 80, \mathrm{CO}_{2} 15\right.$, $\left.\mathrm{O}_{2} 5 \%\right), 37 \mathrm{C}$ で培養を開始し, 菌の増殖を調べた。その 結果 C. jejuni, C. coli 各 (のべ) 20株 (使用菌株数各 5 株 $\times$ 胆汁 4 種) 中生育がみられたものは, 牛胆汁中で おのおの18株，13株で，豚胆汁中では両菌種とも18株で あつた。またこれらの牛胆汁中で増殖しないC. coli は ほとんど人由来のものであつた。このことは人から $C$. coli より C. jejuni が多く分離されやすいことに胆汁が 関係していること, また人由来の C. coli と豚由来の C. coli は別に異なる要素があることが考えられる。

13. 嫌気連統培意における Escherichia coli の Shigella flexneri, Vibrio parahaemolyticus および Staphylococcus aureus に対する強い增殖抑制

○牛嶋 腲, 高橋めぐみ, 尾崎良克（滋賀医大・微生 物)

三種の下乘起因菌, S. flexneri, V. parahaemolyticus および $S$. aureusを, おのおの消化管内優位常在菌群, Bacteroides ovatus, Fusobacterium varium, Bifidobacterium adolescentis, E. coli, Streptococcus faecalis など と嫌気連続培養したところ, 前者は $2 \sim 10$ 日の間に消失 し, 検出できなくなつた。培地の窒素, 炭素源量を増量 しても, 結果に変動はみられなかつた。この増殖抑制の 主役は, E. coli で, 本菌を除くと, 下㶡起因菌は, 増殖 定着可能となつた。ただし，S. aureus は, S. faecalis によつても，E. coli とほぼ同等の抑制を受けた。Clostridium perfringens も, E. coli により強い増殖抑制を 受けたが, 窒素源の増量で抑制が弱まり増殖定着した。 これらの抑制機序は不明である。

\section{4. 半流動寒天培地における Yersinia 菌の検討お} よび增菌後の分離に及ぼす酢酸タリウムの選択性 $(\mathbf{1})$

○浜野理一郎, 佐々木美幸, 島田裕見子（箕面市立病 院)

Yersinia 菌の増菌法は, 主としてリン酸緩衝液が採用 されている。しかし低温菌である Pseudomonas 菌の増 殖のため, 選択性に欠き, 長期間の培養が必要なため, あまり普及されていない。そこでわれわれは，酢酸タリ ウムが, 特にPseudomonas 菌を強く抑制することを認 め, 増菌後の分離に採用し好結果をみた。さらに酢酸夕
リウム加 CIN 培地は, 材料からの Y. ent の分離効果 も高めることも認めた。また, 増菌培養に OF 培地 $(2 / 3$ 寒天濃度) の採用により, 上層部発育, 培地の黄変など の選択性を認めた。特に Y. pst の上層部発育は顕著で, 培地変化が認められない場合も, 上䅉部より純培養状に 分離され, さらに平板培地で Y. pst は特有の発育が観 察された。以上より，両者はとるに選択性にすぐれ，臨 床応用に有用と思われる。

\section{Leuconostoc mesenteroides B 1375 株が産生す} るテキストランの構造と特異性

○鳥居光雄, 田中節子, 渡部一仁, 越川富比古, 山添 まり(摂南大・薬・衛生微生物)

Leuconostoc mesenteroides B 1375 株がつくるデキスト ランは $\alpha-(1 \rightarrow 6)-\mathrm{D}-$ グルカン主鎖のグルコース残基の約 16\%にD-グルコースが $\alpha-(1 \rightarrow 3)$ 結合した分肢構造をも つものといわれている。そこでこれと類似する種々の合 成デキストランと比較しながら沈降反応, 沈降反応阻害 などの免疫化学的方法でその構造を確認するとともに抗 原特異性を明らかにした。すなわち，本デキストランは 少くとも 2 種類の抗原決定基をもち，その一つは D-グ ルコースの $\alpha-(1 \rightarrow 6)$ 直鎖構造で, その長さはペンタサ ッカライドに相当するすのであり, 今一つは D-グルコ 一スの $\alpha-(1 \rightarrow 3)$ 分肢点を含む分肢構造そのものであろ うと考えられる。

\section{Serratia 感染症 (Opportunistic infection) に}

\section{関する一私見}

○多田宜文，山口淳二(近畿大・医・細菌)

S. marcescens の患者分離株を用いて，カルベニシリ ンによるスフェロプラスト形成, 桿菌への復帰および viability を定量的に調べた。一般に，スフェロプラスト は浸透圧に感受性であることが知られているが, S. marcescens は等張条件下でも $50 \%$ をこえるスフェロプラス ト形成を示し，高い復帰能をもつこと，また，復帰に際 しても, 必らずしも強い高張条件を必要としないことが わかつた。さらに, スフェロプラストを最少阻止濃度程 度のカルベニシリンの存在下で24時間培養しても, $20 \%$ 程度の viability (復㴆能) を保持していた。これらの事 実は, 体内におけるスフェロプラスト形成の容易さ, 安 定な viability, 復帰率の高さを示唆しており,このこと が，S. marcescens が日和見感染症の 原因菌になる 重要 な原团であると考えられる。 


\section{Bacillus megaterium の芽胞形成期における 芽}

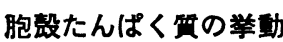

○奥 裕一, 寺岡美恵, 大塚幹子, E.I. フセイン, 中 谷喜洋, 今川正良, 西原 力, 近藤雅臣 (阪大・薬・ 衛生化学)

B. megaterium ATCC 12872 菌芽胞のコートたんぱ く質全体に対する抗体を調製し，これを用いて芽胞形成 期細胞の cytoplasm fr. と前駆芽胞のたんぱく質を含む SDS-DTT fr. について sandwich EIA を行つた。そ の結果コートたんぱく質の生合成は $\mathrm{t}_{2}$ より開始され, $\mathrm{t}_{4}$ から $\mathrm{t}_{8}$ にかけてもつとも盛んであり, また $\mathrm{t}_{6}$ 前後に cytoplasm fr. 中に存在するコートたんぱく質は SDSDTT fr. 中のそれの約3\%程度にすぎないことが示され た。SDS-DTT fr. についてイムノブロットを行うと, コートたんぱく質は異なつた分子量のものがさまざまな 時期に合成沈着されていることがわかつた。

\section{8. 性ホルモンの淋菌感染に及ぼす影響}

○西 一幸, 江本正志, 喜多英二, 樫葉周三(奈良医 大・細菌)

血中エストロジェン值の高い雌マウスが, 淋菌の胵腔 内感染に高い感受性を示すことから, DGI をモデルに してェストロシェンの淋菌感染に対する感受性立進の要 因を検討した。エストロジェン処置マウスは，DGI 感 染において正常マウスに比して100倍高い感受性を示し， Bacteremia に対する $\mathrm{ED}_{50}$ は $10^{3.8} \mathrm{CFU}$, death に対

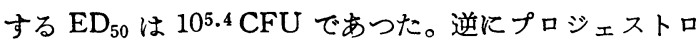
ン処置マウスでは, $10^{9} \mathrm{CFU}$ 以上を接種してもマウスの 死亡は認められなかつた。この差異は, エストロシェン 処置マウスに括ける多形核白血球の走化能抽よび $\mathrm{MPO}$ 依存性の殺菌能が著しく低下していることが要因と考え られた。

\section{Bacillus thuringiensis の産生する溶血毒}

○本田武司, 芝 敦子, 三輪谷俊夫（阪大・微研）

B. thuringiensis の産生する溶血毒を硫安沈殿 $(85 \%)$ $\rightarrow$ DEAE cellulose $\rightarrow$ Hydroxyapatite $\rightarrow$ Sephader G 75 を用いて精製した。精製毒素は，Disc 電気泳動，SDS polyacrylamide slab gel 電気泳動で 1 本の band に泳 動された。分子量は $68,000, \mathrm{pI}$ は 6.5 と算定された。 精製溶血毒は, $50 \mathrm{mM}$ の Dithiothreitol 処理で $2 \sim 8$ 倍活性化された。対照に用いた $B$. cereus の精製溶血毒 も分子量, $\mathrm{pI}, \mathrm{DDT}$ による活性化などもまつたく同じ 性状を示した。また B. cereus の溶血毒に対する抗血清
にB. thuringiensis の溶血毒は反応した。

以上の成績から，B. thuringiensis は B. cereus の産 生する cereolysin ときわめて類似した溶血毒を産生し ていることが明らかになつた。したがつて，農薬として B. thuringiensis の生菌散布に 解決すべき問題が残つて いると考えられた。

20. 豚由来毒素原性大晹菌 WT-1 が産生する LT の B subunit の一次構造

○过 孝雄, 本田武司, 三輪谷俊夫, 若林貞夫*, 松 原 央*(阪大・微研, *阪大・理)

豚より分離した毒素原性大腸菌の産生する易熱性エン テロトキシン (LT) の B subunit の一次構造の解析を 行つた。菌株は竹田らによつて E. coli 320-1 の Ent plasmid を E. coli 20-SO に transfer した E. coli WT-1 を用いて行つた。その結果, Dallas \& Falkow が DNA 側より解析した一次構造と 1 简所アミノ酸に違 いが認められた。Dallas \& Falkow らは, N-terminus より43番目が，Metと報告しているがたんぱく側から解 析した結果 Met ではなくLys であつた。このことか ら CT, LTh と LTp の B subunit の違いは, Mekalanos, Lai \& Yamamoto らの報告をあわせると 3 者と も異なる箇所は，N-terminusより 4 と103番目で, CT, LTh と共通で LTp の異なる箇所が46番目である。

21. 乳のみマウス鵱管液体貯留をきたす $V$. cholerae non-01 の産生する毒掌

○有田美知子, 本田武司, 三輪谷俊夫 (阪大・微研)

$V$. cholerae non-01 の産生する乳のみマウス腸管内液 体貯留毒素の産生条件を検討し， $0.5 \% \mathrm{NaCl}$ 加 $\mathrm{BHI}$ ブロスで37C，14時間振温培養する方法が良いことがわ かつた。乳のみマウスに毒素標品を投与後 2 〜時間で 液体貯留はもつとも強かつた。粗毒素では60C30分で失 活し，100C 加熱では10分では失活しなかつたが30分で は失活した。保存株 108 株について環境由来株 8 株中 5 株がまた患者由来株では 100 株中55株が主毒素を産生し ていた。培養上清を硫安沈殿, DEAE-Cellulose, Sephacryl S-200, Hydroxyapatite, Sephadex G-75 で部 分精製を行つたところ本毒素と溶血毒とは明らかに別の 位置に溶出され溶血毒とは異なつた毒素であることがわ かつた。また本毒素の液体貯留活性は抗コレラ毒素で中 和されなかつた。

22. コレラ毒素および大罢菌场熱性毒索（LTp および 
LTh）に対するウサギ抗血清中の共通抗体の定量的解析 ○余 明順, 王 悦治, 辻 孝雄, 本田武司, 三輪谷 俊夫 (阪大・微研)

CT, LTh，LTp の間に免度学的共通性が存在するこ とはすでに報告されているが，兔疫学的共通性を利用し たワクチンへの開発などの基礎資料とするために今回わ れわれはこれら 3 種のエンテロトキシンの免疫学的類 似性を定量的に解析することを試みた。定量法として Immuno affinity column 法, 逆 Mancini テストの 2 つを用いたが，いずれの結果もきわめて近似しており， LTh-LTp 間, LTh-CT 間の共通性は70 80\%と高く, LTp-CT 間の共通性は60\%前後と低いことがわかつた。 またこの結果は,アミノ酸配列から推察される成績とも よく相関していた。

\section{Clostridium difficile の産生する enterotoxin に} 対する抗体価の ELISA 法による測定

○加藤隆弘, 本田武司, 三輪谷俊夫 (阪大 - 微研)

家鬼免疫血清および健康成人血清を用いて抗 $C$. difficile エンテロトキシン抗体を ELISA 法で測定した。家 鬼エンテロトキシン免疫血清では，1,000倍～256,000倍 の血清希釈倍数で抗体が検出でき，同時に施行したマウ ス致死中和試験, $\mathrm{CHO}$ 細胞 elongation の中和試験と この ELISA 法の成績は上く相関し, 高い特異性が認め られた。しかもELISA 法は高感度であつた。一方, 同 一の ELISA の系で健康成人血清中の抗体の存在を検討 したところ，有意に上昇した抗体の検出は困難であっ た。このことより健康成人血清中では, 抗体が存在して も微量であり, 逆に ELISA 法で有意に抗体陽性となつ た場合, その診断的意義が高いと考えられる。今後, ELISA 法の方法論的問題とともに, 偽膜性腸炎患者血 清中の抗体価の測定も試みる予定である。

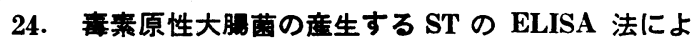 万定量}

○竹田多恵, N. パタラランロン, 本田武司, 三輪谷 俊夫, 竹田美文1), W.ヘメルホプ2), J.-P. バッラー2) (阪大・微研, 1)東大・医科研, 2)ベルギー自由大)

STh に対するモノクローン抗体を用いて, competitive ELISA 法によるST の定量を試みたところ, STh, $\mathrm{ST} \mathrm{p}$ ともに約 $1 \mathrm{ng} / \mathrm{m} l$ から測定できた。これは乳のみ マウス法より感度が 20〜30 倍すぐれている。また STh と STp にのみ特異的で, LT や STb ブタにのみ病原
性を示す ST) とは反応しなかつた。判定は肉眼でです 容易で, 結果は 6 時間で得られた。200 株の大腸菌の培 養上清を用いて ST 産生性を調べると，乳のみマウス法 の結果とすべて一致した。

\section{5. カルボシアニン色素による細菌・酵母メタクロ マジー染色}

○大橋邦啓, 梅田 優*, 藤田益子, 丹羽 允(大阪市 大·医・細菌, *同・泌尿器)

フィルムの感光増感剤として開発されたカルボシアニ ン DBTC は現在まで生物医学方面では, そのメタクロ マジー性により, 組織化学, あるいはLPS などの定量 に用いられてきた。われわれは，この色素を細菌・酵母 の染色に応用した。その結果, E. coli, P. aeruginosa などグラム陰性菌は赤乃至 赤紫色に, S. epidermidis, G. tetragena，B. subtilis などグラム陽性菌は青紫色に 染め分けられた。一方, 酵母の方では出芽酵母の Saccharomyces cerevisiae の栄養細胞は赤紫色に染色され たが，子のうは難染性であつた。分裂酵母の Schizosaccharomyces pombe の栄養細胞は赤紫色に染色された。 さらに接合子形成後の細胞は菌体の赤紫色に加兄表層が 青色に染色された。また, この場合, 胞子は赤紫色に染 色された。

\section{6. カルボシアニン色素による真菌のメタクロマジー} 染色

○藤田益子, 大橋邦啓, 梅田 優*, 丹羽 允 (大阪市 大・医・細菌, *泌尿器)

細菌・酵母同様カルボシアニン DBTC のメタクロマ ジー性を真菌に利用した。その結果細菌ではグラム陽性 菌は主として青紫色系に, グラム陰性菌は赤紫色系に染 まるのと異なつて真菌では菌種によつてはもちろん, 同 一菌種でも胞子・分生子・菌系等分部によつても, 成長 過程の段階によつても染色性が異なり，実にカラフルな メタクロマジー染色が観察された。次にこの染色液の抗 菌性を調べた。グラム陽性菌, グラム陰性菌では $\mathrm{R}$ 型 菌, 酵母 (Sijo, Pombe) 抢上び真菌に著しい抗菌性を示 し, グラム陰性菌では $\mathrm{S}$ 型菌, 酵母 (S. cerevisiae) は 染色液の有無に関係なく増殖が認められた。以上のこと は菌体成分や細胞壁成分の差異などが反映されていると 考えられ，この染色のメカニズムについて今後さらに検 討したい。 